\title{
Cultura Cultura
}

\section{J. Martins Lampreia, Lóbi - ética, técnica e aplicação, Lisboa, Texto Editores, 2005, 128 pp.}

\section{Carlos Leone}

\section{(2) OpenEdition}

1 Journals

\section{Edição electrónica}

URL: http://journals.openedition.org/cultura/2314

DOI: $10.4000 /$ cultura. 2314

ISSN: 2183-2021

\section{Editora}

Centro de História da Cultura

\section{Edição impressa}

Data de publição: 1 janeiro 2006

Paginação: 391-392

ISBN: 0870-4546

ISSN: 0870-4546

\section{Refêrencia eletrónica}

Carlos Leone, «J. Martins Lampreia, Lóbi - ética, técnica e aplicação, Lisboa, Texto Editores, 2005, 128 pp. », Cultura [Online], Vol. 22 | 2006, posto online no dia 11 março 2016, consultado a 24 setembro 2020. URL : http://journals.openedition.org/cultura/2314; DOI : https://doi.org/10.4000/ cultura. 2314

Este documento foi criado de forma automática no dia 24 setembro 2020.

(c) CHAM - Centro de Humanidades / Centre for the Humanities 


\title{
J. Martins Lampreia, Lóbi - ética, técnica e aplicação, Lisboa, Texto Editores, 2005, $128 \mathrm{pp}$.
}

\author{
Carlos Leone
}

\section{REFERÊNCIA}

J. Martins Lampreia, Lóbi - ética, técnica e aplicação, Lisboa, Texto Editores, 2005, 128

pp.

\section{Portugal e a Europa: o caso dos lóbis}

Palavra geralmente mal conotada, e pior compreendida, ««lobby»» já foi 'aportuguesada' mas continua a ser mal empregue. Se se acreditar na bondade intrínseca do mundo das Letras é coisa para estranhar, especialmente depois da publicação deste livro; mas, conhecendo o modo como normalmente as coisas se passam, é apenas lógico. Depois de várias obras sobre temas hoje comuns, mas na altura dos seus trabalhos ainda pouco estudados (técnicas de comunicação, assessoria de Imprensa, comunicação empresarial, gestão de crise), J. Martins Lampreia publicou no final de 2005 uma obra dedicada à sua actual causa e, como já sucedera anteriormente (especialmente ao escrever sobre gestão de crise), a sua visão europeísta das realidades associadas ao lóbi torna este trabalho invulgar e valioso, mas suscitará ainda por bastante tempo resistências várias e não declaradas. Como observa, no prefácio, José Miguel Júdice, «Portugal é um país profundamente conservador e com uma cultura de hipocrisia e de "manhosice" proverbiais» (p. 9). E, por ser assim, aquele que é o grande objectivo do autor neste trabalho e noutras iniciativas, a regulamentação legal do lóbi em Portugal, é uma causa cívica. 
Apesar de logo no preâmbulo o autor declarar que este é um trabalho essencialmente técnico (p. 13), isso não obsta a que a divulgação da técnica de lóbi se revista, no contexto português, de uma faceta não neutra, isto é, de intervenção política descomprometida em defesa de um bem comum (o que, grosso modo, irei referir como civismo). Na sua estrutura este livro corresponde ao seu título: a ética do lóbi (o seu carácter próprio), são abordados nos capítulos 2 e 3 (definições, regulamentos), já aí numa perspectiva europeia - e por fortes razões a que nos referiremos daqui a pouco; as técnicas que compõem a actividade são objecto da parte de leão do livro, capítulos 4 a 6 (abrangendo meios, intervenientes, etc.); por fim, a aplicação e a aplicabilidade futura do lóbi são analisadas nos dois últimos capítulos. O carácter técnico do conjunto não desilude, ao oferecer não só informação habitualmente não acessível ao público não especializado mas também por indicar fontes (sobretudo na internet) que servirão de meios para os interessados poderem continuar o seu percurso no estudo do tema. Contudo, é a dimensão cívica desse conjunto que distingue este trabalho e reclama uma crítica mais do que uma notícia do seu lançamento.

Aquilo que se encontra descrito no livro de Martins Lampreia é um, mais um, retrato da longa pré-modernidade portuguesa, que hoje degenera, em coisas como esta e muitas outras, em submodernidade. De novo nós e a Europa, ainda como um par desavindo, pois da nossa parte verifica-se uma rejeição da modernidade precisamente por parte daqueles (as ditas «elites») que mais a deveriam viver. Nada disto é novo: o ensaísmo cívico português do início do século XX, de homens como os 'seareiros', muito notou esta pré-modernidade (à qual ninguém era completamente imune); e mesmo na segunda metade do século alguma da melhor sociologia portuguesa (por sinal de autores tão diferentes como Hermínio Martins ou Adérito Sedas Nunes) observou o modo como as elites portuguesas não promovem a modernização na sociedade, antes optam repetidamente por manter o statu quo enquanto ensaiam uma subversão dos dados da técnica moderna em seu favor particular, apelando ao «respeitinho», etc. Sucede que estas estratégias de dominação social dependeram sempre de uma situação de isolamento político face à modernidade europeia, que justamente se perdeu com a adesão à CEE e hoje se prolonga na União Europeia. (E talvez este fosse motivo suficiente para não ver na actual República apenas uma reedição da Primeira, mas esse é assunto para outras discussões). Este livro é escrito, nitidamente, a partir da perspectiva europeia que já referimos e identificámos também em trabalhos anteriores do autor, por isso não surpreende o silêncio que acompanhou o seu lançamento: nele se contraria aquela desinformação sistematicamente promovida em torno do termo lóbi que visa melhor se manter o tipo de situação que se acusa o lóbi de promover, num conservadorismo cleptocrático que se estende desde a extrema direita à extrema esquerda.

O contraste entre a situação comum na União Europeia no que toca à regulamentação do lóbi e o que sucede em Portugal, mesmo se mitigado por uma razoável diversidade na regulamentação e por uma afinidade pré-moderna dos países do sul da Europa, resulta bem claro para o leitor. A defesa do modelo ocidental de democracia liberal empreendida por Martins Lampreia através da regulamentação das actividades de lóbi e «public affairs» surge como um compromisso cívico livre das guerras de alecrim e manjerona em torno do federalismo, da Constituição, etc. - trata-se de um compromisso que resulta de escolhas quanto à acção e aos modos correctos para a empreender, sem buscar na discusão um modo de se eximir à responsabilidade social da acção, à sua inevitabilidade. Caso claro disso mesmo é a atenção não só ao quadro 
europeu mas também a outros (EUA e Canadá) fora dos esquemas de oposição primários repetidos por todos os conservadorismos escondidos atrás de discusões que visam manter o acordo tácito (quando não explícito) sobre 'a ordem das coisas'. Dada a brevidade do livro, as diferenças na ética e na prática de lóbi entre europeus modernos e americanos não é muito explorada, mas fica claro que o autor tem bem presente como essa diferença se deve em muito às numerosas outras diferenças políticas e sociais (em particular na relação com os mass media) patentes nos dois blocos.

Mas ainda maior do que a distância entre o lóbi americano e o europeu, é a distância entre os que na Europa persistem na pré-modernidade (a perorar contra a globalização) e os que vivem em sociedade modernas. Sinal de como estas circunstâncias não nos são exclusivas é a já acertada publicação de uma tradução desta obra em Espanha. Caso raro e que torna as iniciativas do autor nesta área ainda mais merecedoras de atenção, pois, como se lê na p. 62, na nossa actual geopolítica todos os caminhos vão dar a Bruxelas. Não é de estranhar, até porque a história moderna de Portugal indica claramente que as grandes mudanças no país ocorrem sempre não por iniciativa própria mas por resposta a pressões exteriores. E, sintomaticamente, Martins Lampreia escreve «esperemos agora por uma directiva comunitária, no sentido de mudar as coisas. Pode ser que a partir daí se possa escrever a história do lóbi em Portugal.» (p. 25). Este livro será parte indispensável dessa história. 